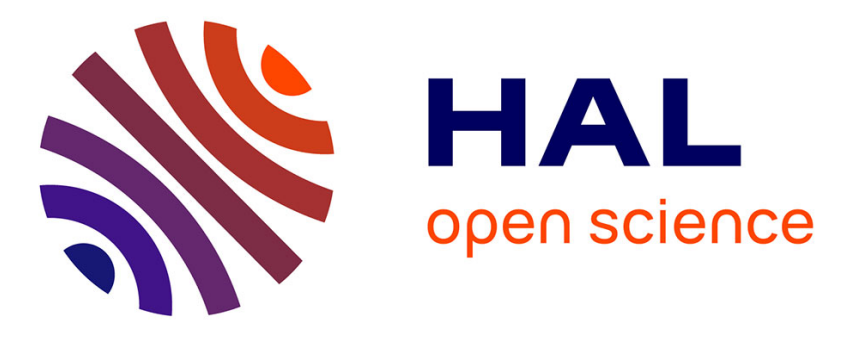

\title{
Changes in faecal bacteria and metabolic parametersin foals during the first six weeks of life
}

\author{
Juliane Kuhl, Nora Winterhoff, Manuela Wulf, Florian J. Schweigert, Ilse
} Schwendenwein, Rupert M. Bruckmaier, Jörg E. Aurich, Peter Kutzer, Christine Aurich

\section{To cite this version:}

Juliane Kuhl, Nora Winterhoff, Manuela Wulf, Florian J. Schweigert, Ilse Schwendenwein, et al.. Changes in faecal bacteria and metabolic parametersin foals during the first six weeks of life. Veterinary Microbiology, 2011, 151 (3-4), pp.321. 10.1016/j.vetmic.2011.03.017 . hal-00717085

\section{HAL Id: hal-00717085 \\ https://hal.science/hal-00717085}

Submitted on 12 Jul 2012

HAL is a multi-disciplinary open access archive for the deposit and dissemination of scientific research documents, whether they are published or not. The documents may come from teaching and research institutions in France or abroad, or from public or private research centers.
L'archive ouverte pluridisciplinaire HAL, est destinée au dépôt et à la diffusion de documents scientifiques de niveau recherche, publiés ou non, émanant des établissements d'enseignement et de recherche français ou étrangers, des laboratoires publics ou privés. 


\section{Accepted Manuscript}

Title: Changes in faecal bacteria and metabolic parametersin foals during the first six weeks of life

Authors: Juliane Kuhl, Nora Winterhoff, Manuela Wulf, Florian J. Schweigert, Ilse Schwendenwein, Rupert M.

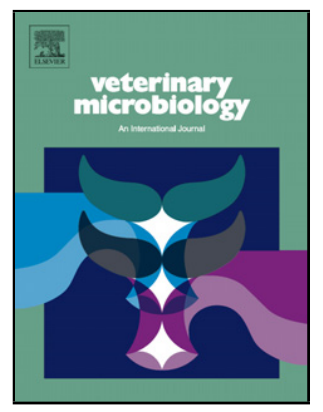

Bruckmaier, Jörg E. Aurich, Peter Kutzer, Christine Aurich

PII:

S0378-1135(11)00172-6

DOI: doi:10.1016/j.vetmic.2011.03.017

Reference: VETMIC 5240

To appear in: $\quad$ VETMIC

Received date: 29-9-2010

Revised date: 14-3-2011

Accepted date: $\quad$ 17-3-2011

Please cite this article as: Kuhl, J., Winterhoff, N., Wulf, M., Schweigert, F.J., Schwendenwein, I., Bruckmaier, R.M., Aurich, J.E., Kutzer, P., Aurich, C., Changes in faecal bacteria and metabolic parametersin foals during the first six weeks of life, Veterinary Microbiology (2010), doi:10.1016/j.vetmic.2011.03.017

This is a PDF file of an unedited manuscript that has been accepted for publication. As a service to our customers we are providing this early version of the manuscript. The manuscript will undergo copyediting, typesetting, and review of the resulting proof before it is published in its final form. Please note that during the production process errors may be discovered which could affect the content, and all legal disclaimers that apply to the journal pertain. 
1 Changes in faecal bacteria and metabolic parametersin foals during the first

115 Institute for Physiology, Vetsuisse Faculty, University of Berne, Berne, Switzerland 12

\section{six weeks of life}

Juliane Kuhl $1,4^{*}$, Nora Winterhoff 2 , Manuela Wulf 1 , Florian J. Schweigert ${ }^{3}$, Ilse Schwendenwein ${ }^{4}$, Rupert M. Bruckmaier 5 , Jörg E. Aurich 4 ,

Peter Kutzer ${ }^{2}$, Christine Aurich 1,4

${ }^{1}$ Graf Lehndorff Institute for Equine Science, Neustadt (Dosse), Germany ${ }^{2}$ Berlin - Brandenburg State Laboratory, Frankfurt (Oder), Germany

3Institute for Nutritional Science, University of Potsdam, Potsdam, Germany

4 University of Veterinary Science, Vienna, Austria

${ }^{*}$ Corresponding author at Graf Lehndorff Institute for Equine Science 16845 Neustadt (Dosse), Germany, e-mail juliane.kuhl@vetmeduni.ac.at, tel. $+43-125077-6405$, fax $+43-125077-5490$ 
20 Many foals develop diarrhoea within the first two weeks of life which has been 21 suggested to coincide with postpartum oestrus in their dams. To analyse the pathogenesis of this diarrhoea we have determined faecal bacteria in foals and their

23 dams ( $\mathrm{n}=30$ each), and serum IGF-1 and y-globulins for 6 weeks after birth. In 24 addition, effects of $B$-carotene supplementation to mares (group 1: $1000 \mathrm{mg} / \mathrm{day}$, $25 \mathrm{n}=15$, group 2: control, $\mathrm{n}=15$ ) on diarrhoea in foals were studied. Diarrhoea occurred 26 in 92 and $79 \%$ of foals in groups 1 and 2, respectively, but was not correlated with 27 oestrus in mares. Beta-carotene supplementation was without effect on foal 28 diarrhoea. In mares, bacterial flora remained stable. The percentage of foals with 29 cultures positive for $E$. coli was low at birth but increased within one day, the 30 percentage positive for Enterococcus sp. was low for 10 days and for Streptococcus 31 sp. and Staphylococcus sp. was low for 2 to 4 weeks. By 4 weeks of age, bacterial 32 flora in foals resembled an adult pattern. Concentration of serum IGF-1 was low at 33 birth (group 1: 149 \pm 11 , group 2: $166 \pm 17 \mathrm{ng} / \mathrm{ml}$ ), increased after day 1 (day 7 group 1: $34384 \pm 30$, group 2: $372 \pm 36$ ) but at no time differed between groups. Serum $y$-globulin concentration in foals was low before colostrum intake and highest on day $1(p<0.001$

36 over time). In conclusion, neonatal diarrhoea in foals does not coincide with 37 postpartum oestrus in their dams but with changes in intestinal bacteria and is not 38 influenced by $\beta$-carotene supplementation given to mares.

40 Keywords: foal; diarrhoea; faecal bacteria; IGF-I; carotene supplementation 41 


\section{Introduction}

Many foals develop transient diarrhoea in the first two weeks of life. This condition has been suggested to coincide with first oestrus after parturition in their dams and is often named foal heat diarrhoea. This diarrhoea is non-infectious and self-limiting but little is known about the causative factors. Changes in milk composition (Johnston et al. 1970), postnatal maturation of the gastrointestinal tract and establishment of intestinal bacterial flora have been suggested (Masri et al. 1986). Foals are born with virtually no immunoglobulins and passive transfer of maternal immunoglobulins via colostrum is required to provide protection against infections in the neonatal period (McGuire et al. 1977, LeBlanc et al. 1992). In addition to immunoglobulins, colostrum contains a variety of growth factors (Hess-Dudan et al. 1994, Berg et al. 2007, Stelwagen et al. 2009). In cattle and pigs, positive effects of colostrum on development of the intestinal mucosa have been demonstrated (Xu 1996, Bühler et al. 1998).

Beta-carotene is present in equine colostrum at high concentrations (Schweigert and Gottwald 1999) and transferred to the foal via colostrum (Kuhl et al., 2010). In calves, $\beta$-carotene status may affect the occurrence of diarrhoea (Kume and Toharmat 2001). Clinical reports but no controlled studies indicate positive effects of $\beta$-carotene supplementation to mares on diarrhoea in their foals (Enbergs and Klemt 1987).

In the current study, changes in faecal bacteria and parasites of newborn foals and their dams were analysed from foaling until 6 weeks after birth. We hypothesized that foal heat diarrhoea is not linked to postpartum oestrus but is associated with changes in intestinal bacterial flora. Factors potentially influencing intestinal maturation,

67 function and immunity such as IGF-1 concentration and serum y-globulins were 68 analysed as well. In addition, effects of B-carotene supplementation to mares on 69 faecal bacterial flora and occurrence of neonatal diarrhoea in their foals were studied. 


\section{Material and Methods}

\subsection{Animals and sampling procedures}

A total of 30 mares and their foals of the Brandenburg State Stud (Neustadt/Dosse, Germany) were included into the study. Foals were born between March and May. Details on the animals are given in table 1.

Mares were kept in group stables and had access to an outdoor paddock for several hours every day. Approximately two weeks before the expected date of foaling, mares were transferred to individual boxes and were returned to their group together with the foal 5 days after parturition. Mares were fed concentrates and hay twice daily and had free access to fresh water at all times. Foals were fed a pelleted foal starter in an area of the group stable not accessible to the mares and had also access to the mares' hay. When the foals had reached an age of 3 to 4 weeks, the group was turned out on pasture. Mares were dewormed with ivermectin (Eraquell, Virbac, Bad Oldesloe, Germany) on the day of foaling and on day 28 thereafter if not yet pregnant again. All foals received ivermectin on day 28 of life. Three foals were excluded from the study for reasons not related to the experiment (one foal treated for meconium impaction in a veterinary clinic from days 2 to 7 of life, one foal receiving systemic antibiotic treatment because of a superficial wound with local swelling on the first day of life, one foal receiving antibiotic treatment because of profound diarrhoea with signs of clinical illness between days 22 and 32 of life).

\subsection{Experimental design}

Mares were tested daily for oestrous behaviour with a teaser stallion, beginning on day 6 postpartum. In addition, signs of oestrus were checked by rectal palpation and 
ultrasonography of the ovaries and uterus at one to two-day intervals. Oestrus was defined using standard criteria (Behrens et al. 1993). Foals were checked daily for signs of diarrhoea and/or illness. The presence of watery faeces, smearing of faeces and loss of hair in the perianal area were used as indicators for diarrhoea. To characterize diarrhoea, a score from $0=$ absent, $1=$ mild, $2=$ moderate to $3=$ high grade diarrhoea was used.

For bacteriological analysis, faecal samples were taken from the rectum of the horses using a sterile swab (WDT, Garbsen, Germany) on day -14, 0 (=day of foaling), 14, 28, 42 in mares and on day 0 (=day of birth), 4, 6, 8, 10, 12, 14, 28, 30, $32,34,36$ in foals, respectively. The sampling regime takes into account the expected time of first and second postpartum oestrus in the mares. To observe infestation with intestinal parasites, faecal samples from the mares were taken on days $-14,0,14,28$ and 42 . At the time of collection of faecal swabs from foals, it was always attempted to take also faecal material for parasitological analysis but sufficient amounts of faeces for parasitology $(50 \mathrm{~g})$ could not be obtained at all times. The number of samples evaluated is indicated in the results section. Bacteriologic samples were placed in transport medium (Amies medium without charcoal, WDT), chilled at $5^{\circ} \mathrm{C}$ and transported to the laboratory within 24 hours. Samples for parasitological analysis were shipped without transport medium.

\section{Blood samples for plasma and serum analysis were taken via jugular venipuncture} on day $-14,-7,0,7,14,21,28,34,42$ in mares and on day 0 (= within 1 hour after birth and before first nursing), 1 (=18-36 hours after birth), 3, 7, 21, 28, 34, 42 in foals. Plasma was centrifuged at $1600 \mathrm{~g}$ for $10 \mathrm{~min}$, serum was centrifuged at $2200 \mathrm{~g}$ for 15 min after a waiting period of 2 hours at room temperature. Aliquots of all samples were frozen at $-20^{\circ} \mathrm{C}$ until further processing. 
126 The mares were randomly allocated to two groups. Mares of group $1(n=15)$ received

$127 \quad \beta$-carotene orally (1000 mg per day; Blattiviko beta 8000 , Blattin Mineralfutterwerk

128 Seitschen, Göda, Germany) from 14 days before the expected date of foaling to 42

129 days after parturition. Mares of group $2(n=15)$ remained untreated as controls. The

130 study was approved by the Committee on Animal Experimentation of the Bran-

131 denburg State Office for Consumer Protection, Agriculture and Rural Development.

132

133 2.3. Experimental procedures

134

135 Detection and identification of bacteria in faecal swabs

136 Faecal swabs were plated onto a set of standard media including Columbia agar

137 supplemented with 5\% sheep blood (CA), Gassner agar (GA), Yersinia selective agar

138 (YA; all Oxoid, Wesel, Germany), and anaerobic agar supplemented with 5\% sheep

139 blood and $0.01 \%$ neomycin (AA) (Heipha, Eppelheim, Germany). Incubation was

140 performed as follows: CA and GA aerobically at $36^{\circ} \mathrm{C}$ overnight, YA aerobically at

$14129^{\circ} \mathrm{C}$ for 48 hours, and $\mathrm{AA}$ anaerobically at $36^{\circ} \mathrm{C}$ overnight. For the detection of

142 salmonellae, the swab was inoculated into $10 \mathrm{ml}$ of Preuss's potassium tetrathionate

143 enrichment broth (Merck, Darmstadt, Germany). After overnight incubation at $36^{\circ} \mathrm{C}$,

144 aliquots of $10 \mu \mathrm{l}$ were plated onto Xylose Lysine Desoxycholate agar and Brilliance

145 Salmonella agar (Oxoid). Inoculated agar plates were incubated again at $36^{\circ} \mathrm{C}$

146 overnight. Identification of bacterial isolates was performed by standard

147 bacteriological procedures described elsewhere (Songer and Post 2005).

148 Bacterial quantities on solid media (except post-enrichment) were classified as no

149 growth (score 0 ), sparse growth (<30 colony forming units, cfu; score 1), moderate

150 growth (30-100 cfu; score 2) and pronounced growth (>100 cfu; score 3).

151

152 Parasitology 
153 Flotation using a saturated sodium chloride solution (specific gravity of 1.18-1.20),

154 sedimentation and the Baermann technique were carried out for each faecal sample.

155 Parasitic development stages were identified by morphologic characteristics using a

156 reticule equipped light microscope (magnification 100-400x).

157

$158 \quad$ Insulin-like growth factor 1

159 Serum IGF-1 in foals was measured by RIA using a non-extraction method

160 (Daxenberger et al. 1998). The antiserum was raised in rabbits against bovine IGF-1

161 and showed a cross-reactivity with IGF-2 $<0.002 \%$. Intra and interassay coefficients

162 of variation were 5.1 and $13.4 \%$, respectively.

163

164 Gamma-globulins and total protein

165 Serum electrophoresis was performed by an automated electrophoresis system and

166 densitometric scanning (Menarini Diagnostics, Vienna, Austria). A proportion of the

$16720 \mu$ s serum sample was blotted on a cellulose acetate strip with a plastic support

168 (Mylor). The strip was transferred into the migration chamber filled with buffer

169 solution (1.09\% Tris-hydroxymethyl-aminomethan and $0.5 \%$ 55-diaethylbarbiturate-

170 sodium), the migration time was $15 \mathrm{~min}$ at $140 \mathrm{~V}$. After migration, the strip was

171 blotted and transferred into a staining solution (Ponceau-red-5, 1.5\% trichloracetic

172 acid) for $180 \mathrm{sec}$ and then transferred into a destaining solution (5\% citric acid) for

$173120 \mathrm{sec}$ and into a clearing solution (32\% N-methyl-pyrrolidon, acetic acid, methanol)

174 for $120 \mathrm{sec}$. Drying took $620 \mathrm{sec}$. Densitometric scanning was performed in green

175 light and the readings were performed with Elfolab software (Menarini Diagnostics).

176

$177 \quad$ Statistical analysis

178 Statistical comparisons were made with the SPSS statistics package (version 17.0

179 SPSS, Chicago, Illinois, USA). Because part of the data are based on scoring, non-

180 parametric tests were used throughout. For comparisons between times within 
181 groups test for related samples were used, taking into account the repeated

182 measures in the same animals (Friedman-test: > two time points, Wilcoxon-test:two

183 time points). Comparisons between groups for individual time points were made by

184 Mann-Whitney-U-test. A p-value $<0.05$ was considered significant. All data given are 185 means \pm standard error of mean (S.E.M.).

\section{3. Results}

188 Clinical findings

189 All but one mare showed signs of oestrus within two weeks after foaling with a mean

190 interval of $9.2 \pm 0.4$ days until first observation of oestrus in group 1 and $8.6 \pm 0.5$ days

191 in group 2. Occurrence of first postpartum oestrus did not differ between groups

192 (figure 1). All foals were viable at birth and no problems with regard to first standing

193 and suckling and colostrum intake were observed. Diarrhoea occurred in 92 and 79

$194 \%$ of foals in groups 1 (foals born to B-carotene supplemented mares) and 2 (foals

195 born to control mares), respectively, at least once during the study period (n.s.).

196 Diarrhoea was seen for $4.1 \pm 1.0$ and $2.6 \pm 0.8$ days in groups 1 and 2 , respectively, 197 and was detected for the first time on day $11.0 \pm 1.8$ and $17.9 \pm 3.0$ in foals of group 1 198 and 2 (n.s.). Within the first two weeks of life $62 \%$ and $43 \%$ of foals in groups 1 and

1992 2, respectively, showed diarrhoea at least on one day (n.s.). With the exception of the 200 first 5 days and days 24 to 42 of life, the occurrence of diarrhoea was spread over 201 the whole observation period and not correlated to signs of first postpartum oestrus in 202 the mares (figure 1).

\section{Bacteriology}

205 A variety of bacterial species considered as markers of gastrointestinal flora was 206 isolated from faecal swabs. Bacteria species isolated at least in two individuals per 207 group and at least on two days were E. coli, Enterococcus sp., $\beta$-haemolytic 208 Streptococci and coagulase-negative Staphylococci in both mares and foals, 
Acinetobacter sp. in mares only and Proteus sp. and Klebsiella sp. in foals only. In

210 foals Pantoea sp., Acinetobacter sp., Clostridium perfringens and Citrobacter sp.

211 were seen less frequently, i.e. in less than two individuals per group or not on two

212 days. Only occasionally Pseudomonas sp., Staphylococcus intermedius, Bacillus sp.,

213 Acinetobacter sp., Corynebacterium sp. and Enterobacter sp. were detected.

214 Coagulase-positive Staphylococci, Kluyvera sp., Arthrobacter sp. and apathogenic

215 Yersina entercolitica occurred in one sample each. In mares, single isolates of

216 Proteus sp., Pseudomonas sp., Pantoea sp. and Bacillus sp. could be detected.

217 Klebsiella sp. and Citrobacter sp. were found in one sample each.

219 In mares, bacterial flora remained largely stable throughout the period studied. E. coli 220 was present in all swabs of group 1 and 2 mares throughout the study except for two 221 swabs of group 2 on the day of foaling. Enterococcus sp. was isolated over the whole 222 observation period from between 57 to $93 \%$ of samples with no significant 223 differences between groups. The occurrence of $\beta$-haemolytic Streptococci decreased 224 at the time of parturition in both groups compared to all later time points $(p=0.05)$. 225 Coagulase-negative Staphylococci did not change significantly over time in group 1. 226 In group 2, they were detected in fewer samples on day 0 and 42 compared to day $227-14(p<0.05)$ but did not differ when day -14 was compared to days 14 and 28 and on 228 day 0 compared to days 14 and 42 (figure $2 a$ and c). Average intensity of bacterial 229 growth is summarized in table 2.

231 In foals, occurrence of bacterial species and intensity of growth changed over time.

232 E. coli occurred in 2 out of 13 and 5 out of 14 samples in groups 1 and 2, respective233 ly, directly after birth (n.s.). On day four $12 / 13$ and $13 / 14$ faecal swabs in groups 1 234 and 2, respectively, (n.s.) contained E. coli which could be isolated in all samples 235 from the age of 10 days onwards (Figure 2b). Enterococcus sp. were present in 4/13 236 and 6/14 samples of group 1 and 2, respectively, on the day of birth and in 5/13 and 
$2 / 14$ swabs of group 1 and 2 respectively on day 8 . After the first week of life, the

238 percentage of samples positive for Enterococcus sp. increased significantly $(p<0.05)$

239 in group 2 but only tended to increase in group $1(\mathrm{p}=0.08)$. On day 32, Enterococcus

240 sp. occurred in more faecal swabs from foals of mares treated with $\beta$-carotene than

241 from foals of non-treated mares $(p<0.05$; figure $2 b)$. Beta-haemolytic Streptococci

242 were first isolated on day 4 of life and until day 10 detected in only 1 to 2 samples in

243 both groups. On day 30, $\beta$-haemolytic Streptococci were detected in more samples,

244 i.e. $9 / 12$ in group 1 and $8 / 10$ in group 2 , compared to day $8(p<0.05)$. No samples

245 could be obtained from one foal in group 1 and 4 foals in group 2. Coagulase-negati-

246 ve Staphylococci were isolated in 10/13 and 12/14 swabs in groups 1 and 2, respecti-

247 vely, at the day of birth and in none (group 2) or only one (group 1) of the samples

248 until day 10 where $3 / 11$ and 2/14 samples in group 1 and 2 , respectively, were positi-

249 ve for coagulase-negative Staphylococci. Thereafter, they were present in up to 50\%

250 and $36 \%$ of samples in groups 1 and 2, respectively. Clostridium perfringens was

251 present in one sample of 3 foals ( $n=2$ group $1, n=1$ group 2), in two consecutive

252 samples of one foal (group 1) and in 4 consecutive samples of two foals (group 2).

253 Clostridium perfringens could be detected during the first two weeks of life only and

254 not at later times. Its occurrence was not associated with diarrhoea in these foals.

255 Intensity of bacterial growth in faecal swabs of foals is summarized in table 3.

$257 \quad$ Parasitology

258 Eggs of small strongyles occurred in 12 of 15 faecal samples in mares of both groups 259 on day -14 and in 13 (group 1) and 12 (group 2) of 15 samples on the day of 260 parturition. Eggs of large strongyles occurred in 7 (group 1) and 2 (group 2) of 15 261 faecal samples on day -14 (n.s.) and in 8 (group 1) and 5 (group 2) of 15 samples on 262 the day of parturition (n.s.). No eggs of endoparasites could be detected thereafter. In 263 the foals, one faecal sample was positive for eggs of small strongyles on day 8 . In 
264 the remaining samples $(n=32)$ parasitic stages were non-detectable throughout the 265 study period.

$267 \underline{\text { IGF-1 }}$

268 Concentrations of IGF-1 in serum of foals were low on the day of birth $(149 \pm 11$ and $269166 \pm 17 \mathrm{ng} / \mathrm{ml}$ in groups 1 and 2 , respectively) and decreased slightly but significantly $270(p<0.05)$ until day $1(133 \pm 13$ and $154 \pm 12 \mathrm{ng} / \mathrm{ml}$ in groups 1 and 2 , respectively).

271 Thereafter, IGF-1 concentrations increased continuously during the first week of life 272 (day 7: $384 \pm 30$ and $372 \pm 36 \mathrm{ng} / \mathrm{ml}$ in groups 1 and 2 , respectively, $p<0.001$ versus 273 day 0 ). No further changes were seen between days 7 and 42 . At no time serum IGF2741 concentrations differed between foals born to B-carotene-treated mares and control 275 mares (figure 3a).

\section{$277 \quad$ Gamma-globulins}

278 Concentration of $\mathrm{y}$-globulins in serum was lowest on the day of birth before colostrum 279 intake (group 1: $315 \pm 56$, group 2: $317 \pm 51 \mathrm{mg} / \mathrm{dl}$ ), and highest on day 1 (group 1: $280958 \pm 140$, group 2: $943 \pm 161 \mathrm{mg} / \mathrm{dl}, \mathrm{p}<0.01$ versus day 0$)$. Thereafter, $\mathrm{Y}$-globulin 281 concentration decreased continuously during the first 4 weeks of life (day 28: $492 \pm 46$ 282 and $509 \pm 62 \mathrm{mg} / \mathrm{dl}$ in groups 1 and 2 , respectively, $\mathrm{p}<0.05$ versus day 1$)$. Serum $\mathrm{Y}^{-}$ 283 globulin concentrations at no time differed between foals born to B-carotene-treated 284 and control mares (figure 3b).

\section{Discussion}

288 The majority of foals showed signs of diarrhoea for some time during the first 6 289 weeks of life. Diarrhoea was transient and none of the foals received antibiotic or 290 other treatment. Diarrhoea in the foals occurred throughout the experimental period 291 but was most pronounced during the second and third week of life. There was no 
temporary relation between diarrhoea in foals and first or second postpartum oestrus

293 in their dams. During the first two weeks of life, diarrhoea occurred in approximately

$29450 \%$ of foals only. While older studies have reported a prevalence of foal heat 295 diarrhoea between 75 and $80 \%$ (Rumbaugh 1983, Masri et al. 1986), the total 296 prevalence of diarrhoea in newborn foals between days 5 and 15 of life in our study 297 is in the same range as reported recently by Sgorbini et al. (2008). Onset and 298 duration of diarrhoea in foals of our study was in accordance with occurrence of 299 diarrhoea in orphan foals raised on a milk replacer diet (Cymbaluk et al. 1993). Foal 300 diarrhoea is thus neither an effect of first postpartum oestrus in their dams nor does it 301 occur in all foals. Because no close temporal relation between foal heat and 302 diarrhoea in foals exists, the term foal heat diarrhoea is confusing and its adequacy 303 should be questioned.

305 Beta-carotene supplementation to periparturient mares was without effect on foal 306 diarrhoea. This contradicts the report by Enbergs and Klemt (1987), however in that 307 study, data were not submitted to critical statistical evaluation. In calves, B-carotene 308 status at 6 days of age affects the occurrence of diarrhoea (Kume and Torhamat 309 2001), however, the aetiology of diarrhoea in calves and foals is not comparable. 310 Diarrhoea in neonatal dairy calves is caused either by inadequate feeding manage311 ment or by infectious agents (reviewed by Bartels et al. 2010).

313 Frequency and intensity of bacterial growth in faeces of foals underwent changes 314 especially within the first two weeks of life, i.e. at a time when neonatal diarrhoea 315 occurred in most foals. Faecal bacterial flora represents a combination of shed 316 mucosal bacteria and non-adherent luminal bacteria. It can thus be assumed that the 317 changes in faecal bacterial flora observed in our study are due to changes in the 318 intestinal bacterial flora. Changes in intestinal flora occur in all species and have 319 been analysed in depth in human infants (Palmer et al., 2007). In infants, a first 
rearrangement of the faecal bacterial population occurred around 5 days of age while

321 the transition to an adult-like pattern is found later and usually after the introduction of

322 solid foods. In contrast to humans, foals start to consume small amounts of 323 concentrates already around 10 days of age. To our knowledge, the horse is the only 324 domestic animal species where a non-infectious diarrhoea occurs regularly in most 325 neonates. The temporal coincidence with changes in bacterial flora is no proof yet of 326 a causal relationship and our data do not allow excluding postnatal maturational 327 changes of the intestinal epithelium as a cause of foal diarrhoea.

329 The percentage of foals with faecal cultures positive for E. coli was low on the day of 330 birth but had increased to near $100 \%$ within one day. In contrast, the percentage of 331 foals with faecal cultures positive for Enterococcus sp. remained low for approxima332 tely 10 days before increasing to the same range as in mares. The percentage of 333 faecal cultures positive for Streptococcus sp. and Staphylococcus sp. increased even 334 later, i.e. between two and 4 weeks of life. Consistent with other reports which 335 consider Clostridium perfringens part of the normal intestinal flora in neonatal foals 336 (Yuyama et al. 2004, Tillotson et al. 2002), its presence was not associated with 337 diarrhoea in the foals of our study. By 4 weeks of age, the bacterial flora in foals 338 largely resembled the spectrum isolated from faeces of their dams, indicating that the 339 intestinal bacterial flora had changed from a neonatal to a postnatal pattern. The time 340 window of these changes was closely correlated with the time range for foal 341 diarrhoea. During the first 10 days of life, in foals also coprophagy can be seen 342 (Kazunori et al.1985, Thompson et al. 1988, Cymbaluk et al. 1993). Microorganisms 343 from the faeces of the mares present on the floor of the stable might therefore 344 colonise the intestinal tract of the foals at this time. Interestingly, diarrhoea occurred 345 in approximately $50 \%$ of foals only during the first two weeks of life, although 346 changes in bacterial flora did not differ between foals with and without signs of 347 diarrhoea. Some foals are thus able to develop a postnatal intestinal flora without 
348 diarrhoea. This might be an advantage with regard to growth and weight gain in

349 these foals.

351 Results of a study using the same deworming regimen of the dams as in our 352 experiment indicated that the regimen was efficient to reduce shedding of 353 Strongyloides eggs and that foal diarrhoea was not caused by infestation with 354 Strongyloides westeri (Ludwig et al. 1982). As no mare was shedding eggs of 355 endoparasites postpartum, worm burden can largely be excluded as a cause of 356 diarrhoea in our foals.

358 Colostrum uptake does not only provide the neonate with immunoglobulins but, at 359 least in piglets, enhances also postnatal maturation of the intestinal epithelium (Xu 360 1996, Jensen et al. 2001, Blum and Baumrucker 2008). In pigs, intestinal maturation 361 is not fully complete before 3 weeks of age (Jarvis et al. 1977). It can be assumed 362 that also in foals, maturation of the intestinal tract at large occurs during a 363 comparable time period and may in part be linked to foal heat diarrhoea.

365 In our study, serum IGF-1 reached highest levels within the first week and remained 366 constant thereafter whereas Hess-Dudan et al. (1994) reported an increase over a 367 period of 3 weeks until a plateau phase was reached. Concentrations of IGF-1 in 368 colostrum of mares are high but decrease dramatically within less than 24 hours 369 (Hess-Dudan et al. 1994, Berg et al. 2007). The postnatal increase in IGF-1 370 concentrations in foals therefore is not due to absorption of colostral IGF-1 but to 371 IGF-1 synthesis by the foal. Although, as in calves (Baumrucker et al. 1994) and 372 piglets (Xu 1996), colostral IGF-1 might have local effects on postnatal development 373 of the intestinal epithelium in foals, these effects will take place before the occurrence 374 of neonatal diarrhoea. 
376 Gamma-globulin concentrations in foals were low before first suckling and, as

377 expected, increased rapidly after ingestion of colostrum (Jeffcott 1974, Hess-Dudan 378 et al. 1994). The concentration of y-globulins was highest one day after foaling and 379 decreased thereafter. Another increase was seen after week 4 of life and is 380 apparently due to immunoglobulin synthesis by the foals (Holznagel et al. 2003). 381 There was no period of markedly reduced $y$-globulin concentrations in foals and thus 382 no gap in immunological protection. Neither the occurrence nor the characteristics of 383 neonatal diarrhoea differed between foals with high and with lower plasma $y$-globulin 384 concentration, indicating that neonatal diarrhoea in foals is not affected by passive 385 transfer of immunity via colostrum and not caused by reduced $\mathrm{y}$-globulin transfer in 386 our study. Gamma-globulins were already detectable before first intake of colostrum. 387 This is in agreement with a recent study in cattle, indicating that more than $50 \%$ of 388 calves had detectable serum IgG concentrations before first colostrum uptake 389 (Chigerwe et al. 2008). However, further investigations are needed to determine 390 causes for the comparably high concentration of $y$-globulins prior to first nursing in 391 our foals. Most probably this is caused by the fact that in our study, total y-globulins 392 in serum were measured which consist not only of immunoglobulins but also of 393 additional proteins with no known immune function.

395 In conclusion, neonatal diarrhoea in foals is not linked to postpartum oestrus in their 396 mares but is observed at a time when changes in faecal bacterial flora from a 397 neonatal to a postnatal pattern occur. These changes in bacterial flora in many foals 398 are accomplished without clinical signs of diarrhoea. Beta-carotene supplementation 399 to mares was without effect on neonatal diarrhoea in foals. 
404

405 The authors are grateful to the team of Neustadt (Dosse) State Stud and especially 406 to Walter Teske, Kerstin Stübing and Rainer Stübing for help with the mares and 407 foals. Dr. W. Schliffka, DSM Nutritional Products, Basel, Switzerland is greatfully 408 acknowledged for the supply of $\beta$-carotene.

409

410 


\section{References}

412 Bartels, C.J.M., Holzhauer, M., Jorritsma, R., Swart, W.A.J.M., Lam, T.J.G.M. (2010):

413 Prevalence, prediction and risk factors of enteropathogens in normal and non-normal 414 faeces of young Dutch dairy calves. Prev. Vet. Med. 93, 162-169.

415 Baumrucker, C.R., Hadsell, D.L., Blum, J.W. (1994): Effects of dietary insulin-like 416 growth factor I on growth and insuline-like growth factor receptors in neonatal calf 417 intestine. J. Anim. Sci. 72, 428-433.

418 Behrens, C., Aurich, J.E., Klug, E., Naumann, H., Hoppen, H-O. (1993): Inhibition of 419 gonadotropin release in mares during the luteal phase of the oestrous cycle by endo420 crine opioids. J. Reprod. Fertil. 98, 509-514.

421 Berg, E.L., McNamara, D.L., Keisler, D.H. (2007): Endocrine profiles of periparturient 422 mares and their foals. J. Anim. Sci. 85, 1660-1668.

423 Blum, J., Baumrucker, C.W. (2008): Insulin-like growth factors (IGFs), IGF binding 424 proteins, and other endocrine factors in milk: role in the newborn. Adv. Exp. Med. 425 Biol. 606, 397-422.

426 Bühler, C., Hammon, H., Rossi, G.L., Blum, J.W. (1998): Small intestinal morphology 427 in eight-day-old calves fed colostrum for different durations or only milk replacer and 428 treated with long-R3-insuline-like growth factor I and growth hormone. J. Anim. Sci. $42976,758-765$.

430 Chigerwe, M., Tyler, J.W., Nagy, D.W., Middleton, J.R. (2008): Frequency of 431 detectable serum IgG concentrations in precolostral calves. Am. J. Vet. Res. 69, 791432795.

433 Cymbaluk, N.F., Smart, M.E., Bristol, F.M., Pouteaux, V.A. (1993): Importance of milk 434 replacer intake and composition in rearing orphan foals. Can. Vet. J. 34, 479-486.

435 Daxenberger, A., Breier, B.H., Sauerwein, H. (1998): Increased milk levels of insulin436 like growth factor 1 (IGF-1) for the identification of bovine somatotropin (bST) treated 437 cows. Analyst 123, 2429-2435. 
438 Enbergs, H., Klemt, P.W. (1987): Der Einfluß von $\beta$-Karotin auf Zyklus und

439 Trächtigkeit der Stute sowie auf die Gesundheit der Fohlen. Prakt. Tierarzt 68, 52-60.

440 Hess-Dudan, F., Vacher, P.Y., Bruckmaier, R.M., Weishaupt, M.A., Burger, D., Blum, 441 J.W. (1994): Immunoreactive insulin-like growth factor I and insulin in blood plasma 442 and milk of mares and in blood plasma of foals. Equine Vet. J. 26, 134-139.

443 Holznagel, D.L., Hussey, S., Mihayli, J.E., Wilson, W.D., Lunn, D.P. (2003): Onset of 444 immunoglobulin production in foals. Equine Vet. J. 35, 620-622.

445 Jarvis, L.G., Morgan, G., Smith, M.W., Wooding, F.B.P. (1977): Cell replacement and 446 changing transport function in the neonatal pig colon. J. Physiol. 273, 717-729.

447 Jeffcott, L.B. (1974): Some practical aspects of the transfer of passive immunity to 448 newborn foals. Equine Vet. J. 6, 109-115.

449 Jensen, A.R., Elnif, J., Burrin, D.G., Sangild, P.T. (2001): Development of intestinal 450 immunoglobulin absorption and enzyme activities in neonatal pigs is diet dependent. 451 J. Nutr. 131, 3259-3265.

452 Johnston, R.H., Kamstra, L.D., Kohler, P.H. (1970): Mare's milk composition as 453 related to „foal heat“ scours. J. Anim. Sci. 31, 549-553.

454 Kazunori, I., Soichi, K. I., Toshio, I. (1985): Establishment of intestinal ciliates in new455 born horses. Jpn. J. Vet. Sci. 47, 39-43.

456 Kuhl, J., Wulf, M., Schweigert, F.J., Aurich, J.E., Aurich, C. (2010): Effects of 457 periparturient supplementation with $\beta$-carotene on oestrous cyclicity and fertility of 458 mares during the first 6 weeks after foaling. Reprod. Dom. Anim. 45 (Suppl. 3), 94.

459 Kume, S., Toharmat, T. (2001): Effect of colostral $\beta$-carotene and vitamin A on 460 vitamin and health status of newborn calves. Livestock Prod. Sci. 68, 61-65.

461 LeBlanc, M.M., Tran, T., Baldwin, J.L., Pritchard, E.L. (1992): Factors that influence 462 passive transfer of immunoglobulins in foals. J. Am. Vet. Med. Assoc. 200, 179-183.

463 Ludwig, K.G., Craig, T.M., Bowen, J.W., Ansari, M.M., Ley, W.B. (1982): Efficacy of 464 ivermectin in controlling Strongyloides westeri infections in foals. Am. J. Vet. Res. 44, $465 \quad 314-316$. 
Masri, M.D., Merritt, A.M., Gronwall, R., Burrows, C.F. (1986): Faecal composition in

467 foal heat diarrhoea. Equine Vet. J. 18, 301-306.

468 McGuire, T.C., Crawford, T.B., Hallowell, A.L., Macomber, L.E. (1977): Failure of co469 lostral immunoglobulin transfer as an explanation for most infections and deaths of 470 neonatal foals. J. Am. Vet. Med. Assoc. 170, 1302-1305.

471 Palmer, C., Bik, E.M., DiGiulio, D.B., Relman, D.A., Brown, P.O. (2007):

472 Development of the human infant intestinal microbiota. PloS Biol. 5, e177

473 Rumbaugh, G.E. (1983): Foal heat diarrhea. In Current Therapy in Equine Medicine.

474 Ed E. Robinson. Saunders Co, Philadelphia, 213-214.

475 Schweigert, F.J., Gottwald, C. (1999): Effect of parturition on levels of vitamins A and $476 \mathrm{E}$ and of $\beta$-carotene in plasma and milk of mares. Equine Vet. J. 31, 319-323.

477 Sgorbini, M., Nardoni, S., Mancianti, F., Rota, A., Corazza, M. (2008): Foal-heat 478 diarrhea is not caused by the presence of yeasts in gastrointestinal tract of foals. J. 479 Equine Vet. Sci. 28, 145-148.

480 Songer, J.G., Post, K.W. (2005): Veterinary microbiology: bacterial and fungal agents 481 of animal disease. Elsevier Saunders, St. Louis, MO.

482 Stelwagen, K., Carpenter, E., Haigh, B., Hodgkinson, A., Wheeler, T.T. (2009): 483 Immune components of bovine colostrum and milk. J. Anim. Sci. 87, 3-9.

484 Thompson, K.N., Baker, J.P., Jackson, S.G. (1988): The influence of supplemental 485 feed on growth and bone development of nursing foals. J. Anim. Sci. 66, 1692-1696.

486 Tillotson, K., Traub-Dargatz, J.L., Dickinson, C.E., Ellis, R.P., Morley, P.S., Hyatt, 487 D.R., Magnuson, R.J., Riddle, W.T., Bolte, D., Salman, M.D. (2002): Population488 based study of fecal shedding of Clostridium perfringens in broodmares and foals. J. 489 Am. Vet. Med. Assoc. 220, 342-348.

490 Xu, R.J. (1996): Development of the newborn Gl tract and its relation to 491 colostrum/milk intake. Reprod. Fertil. Dev. 8, 35-48. 
492 Yuyama, T., Shigeki, Y., Shinji, T., Shirou, T., Yukiko, K., Masami, M. (2004):

493 Evaluation of a host-specific lactobacillus probiotic in neonatal foals. J. Appl. Res.

494 Vet. Med. 2, 26-33.

495 
Table 1: Age of the mares and parity (number of foals produced so far)

\begin{tabular}{|c|c|c|c|}
\hline & $\begin{array}{c}\text { Age (years) } \\
\text { Range } \\
\text { (means } \pm \text { SEM) }\end{array}$ & $\begin{array}{c}\text { Parity (number of foals) } \\
\text { Range } \\
\text { (means } \pm \text { SEM) }\end{array}$ & $\begin{array}{l}\text { Number of mares } \\
\text { rebred within the } \\
\text { study period }\end{array}$ \\
\hline Group $1(n=15)$ & $\begin{array}{c}5-17 \\
(8.0 \pm 1.0)\end{array}$ & $\begin{array}{c}1-13 \\
(4.0 \pm 0.9)\end{array}$ & $10 / 15$ \\
\hline Group $2(n=15)$ & $\begin{array}{c}4-19 \\
(8.5 \pm 1.1)\end{array}$ & $\begin{array}{c}1-13 \\
(4.7 \pm 1.0)\end{array}$ & //15 \\
\hline Total $(n=30)$ & $\begin{array}{c}4-19 \\
(8.3 \pm 0.7)\end{array}$ & $\begin{array}{c}1-13 \\
(4.4 \pm 0.6)\end{array}$ & $24 / 30$ \\
\hline
\end{tabular}

497

498 
499 Table 2: Intensity of bacterial growth in mares $(n=15$ group $1, n=15$ group 2; score

500 from 0 to 3 ; data are means \pm SEM)

\begin{tabular}{lcccccc}
\hline Isolated bacteria & Group & Day -14 & Day 0 & Day 14 & Day 28 & Day 42 \\
\hline E.coli & 1 & $2.4 \pm 0.1^{*}$ & $2.3 \pm 0.2$ & $2.6 \pm 0.2$ & $2.5 \pm 0.1$ & $2.8 \pm 0.1$ \\
& 2 & $2.9 \pm 0.1^{*}$ & $2.3 \pm 0.3$ & $2.4 \pm 0.2$ & $2.7 \pm 0.1$ & $2.9 \pm 0.1$ \\
Enterococcus sp. & 1 & $2.1 \pm 0.2^{*}$ & $2.1 \pm 0.3$ & $2.3 \pm 0.3$ & $2.3 \pm 0.3$ & $1.6 \pm 0.4$ \\
& 2 & $2.5 \pm 0.2^{*}$ & $2.1 \pm 0.3$ & $1.5 \pm 0.3$ & $1.9 \pm 0.3$ & $1.9 \pm 0.3$ \\
-haemolytic & 1 & $1.5 \pm 0.3 \mathrm{a}, \mathrm{b}$ & $0.6 \pm 0.3 \mathrm{a}$ & $1.8 \pm 0.2 \mathrm{~b}$ & $2.1 \pm 0.2 \mathrm{~b}$ & $2.5 \pm 0.2 \mathrm{~b}$ \\
Streptococci & 2 & $1.8 \pm 0.3 \mathrm{a}, \mathrm{b}$ & $0.9 \pm 0.3 \mathrm{a}$ & $1.5 \pm 0.3 \mathrm{~b}$ & $1.5 \pm 0.3 \mathrm{~b}$ & $1.9 \pm 0.3 \mathrm{~b}$ \\
Coagulase-neg. & 1 & $0.4 \pm 0.3 \mathrm{a}$ & $1 ., 5 \pm 0.3 \mathrm{~b}$ & $1.1 \pm 0.3 \mathrm{a}, \mathrm{b}$ & $1.1 \pm 0.4 \mathrm{a}, \mathrm{b}$ & $0.9 \pm 0.4 \mathrm{a}, \mathrm{b}$ \\
Staphylococci & 2 & $0.1 \pm 0.1 \mathrm{a}$ & $1.3 \pm 0.3 \mathrm{~b}$ & $0.5 \pm 0.2 \mathrm{a}, \mathrm{b}$ & $0.6 \pm 0.3 \mathrm{a}, \mathrm{b}$ & $1.7 \pm 0.4 \mathrm{~b}$ \\
Proteus sp. & 1 & 0 & $0.1 \pm 0.1$ & 0 & 0 & 0 \\
& 2 & $0.1 \pm 0.1$ & $0.1 \pm 0.1$ & 0 & 0 & 0 \\
Pantoea sp. & 1 & 0 & $0.1 \pm 0.1$ & $0.4 \pm 0.3$ & $0.1 \pm 0.1$ & 0 \\
Acinetobacter & 1 & $0.2 \pm 0.2$ & $0.8 \pm 0.4$ & $0.6 \pm 0.3$ & $0.4 \pm 0.3$ & $0.4 \pm 0.3$ \\
sp. & 2 & 0 & $1.2 \pm 0.4$ & $0.4 \pm 0.3$ & $0.2 \pm 0.2$ & $0.5 \pm 0.3$ \\
\hline signficant & 2 & 0 & 0 & 0 & $0.1 \pm 0.1$ & 0 \\
\hline
\end{tabular}


Table 3: Intensity of bacterial growth in foals from the day of birth to day 36 of life ( $n=13$ group 1, $n=14$ group 2; score from 0 to 3; data are means \pm SEM )

\begin{tabular}{|c|c|c|c|c|c|c|c|c|c|c|c|c|c|}
\hline \multirow{2}{*}{$\begin{array}{l}\text { Isolated } \\
\text { bacteria }\end{array}$} & \multirow[t]{2}{*}{ Group } & \multicolumn{12}{|c|}{ Day after birth } \\
\hline & & 0 & 4 & 6 & 8 & 10 & 12 & 14 & 28 & 30 & 32 & 34 & 36 \\
\hline \multirow[t]{2}{*}{ E.coli } & $1 \mathrm{a}$ & $0.2 \pm 0.2$ & $2.5 \pm 0.2$ & $2.5 \pm 0.2$ & $2.7 \pm 0.1^{*}$ & $2.6 \pm 0.2$ & $2.8 \pm 0.1$ & $2.7 \pm 0.1$ & $2.9 \pm 0.1$ & $2.9 \pm 0.1$ & $2.8 \pm 0.1$ & $2.8 \pm 0.1$ & $2.9 \pm 0.1$ \\
\hline & $2 a$ & $0.8 \pm 0.3$ & $2.2 \pm 0.2$ & $2.4 \pm 0.1$ & $2.2 \pm 0.1^{*}$ & $2.4 \pm 0.1$ & $2.4 \pm 0.2$ & $2.6 \pm 0.1$ & $2.9 \pm 0.1$ & $2.6 \pm 0.2$ & $2.7 \pm 0.1$ & $2.6 \pm 0.1$ & $2.7 \pm 0.1$ \\
\hline \multirow[t]{2}{*}{ Enterococcus } & $1 \mathrm{a}$ & $0.6 \pm 0.3$ & $1.4 \pm 0.4$ & $0.7 \pm 0.4$ & $1.0 \pm 0.4$ & $2.3 \pm 0.4$ & $2.1 \pm 0.4$ & $1.9 \pm 0.4$ & $2.3 \pm 0.3$ & $1.9 \pm 0.4$ & $2.8 \pm 0.1^{*}$ & $2.0 \pm 0.4$ & $2.4 \pm 0.4$ \\
\hline & $2 a$ & $0.8 \pm 0.3$ & $0.4 \pm 0.2$ & $0.4 \pm 0.2$ & $0.3 \pm 0.2$ & $1.4 \pm 0.3$ & $2.1 \pm 0.3$ & $1.3 \pm 0.3$ & $2.3 \pm 0.4$ & $1.9 \pm 0.4$ & $1.5 \pm 0.4^{*}$ & $2.3 \pm 0.3$ & $2.2 \pm 0.3$ \\
\hline$\beta$-haem. & $1 \mathrm{a}$ & 0 & $0.2 \pm 0.2$ & $0.1 \pm 0.1$ & $0.2 \pm 0.2$ & $0.7 \pm 0.4$ & $0.4 \pm 0.2$ & $0.2 \pm 0.2$ & $1.2 \pm 0.3$ & $1.9 \pm 0.4$ & $1.6 \pm 0.4$ & $1.6 \pm 0.3$ & $1.6 \pm 0.4$ \\
\hline Streptococci & $2 \mathrm{a}$ & 0 & $0.1 \pm 0.1$ & $0.3 \pm 0.2$ & $0.4 \pm 0.2$ & $0.4 \pm 0.2$ & $0.4 \pm 0.2$ & $0.7 \pm 0.3$ & $1.3 \pm 0.4$ & $2.1 \pm 0.4$ & $1.5 \pm 0.3$ & $1.6 \pm 0.3$ & $1.7 \pm 0.4$ \\
\hline Coagulase- & $1 \mathrm{a}$ & $1.4 \pm 0.3$ & 0 & $0.2 \pm 0.2$ & $0.2 \pm 0.2$ & $0.8 \pm 0.4$ & $0.5 \pm 0.3$ & $0.9 \pm 0.4$ & $1.5 \pm 0.5$ & $1.4 \pm 0.4$ & $0.7 \pm 0.4$ & $0.7 \pm 0.4$ & $0.3 \pm 0.3$ \\
\hline neg. Staph. & $2 a$ & $1.9 \pm 0.3$ & 0 & 0 & 0 & $0.4 \pm 0.3$ & $0.8 \pm 0.4$ & $0.9 \pm 0.4$ & $0.7 \pm 0.4$ & $0.6 \pm 0.4$ & $0.9 \pm 0.4$ & $0.8 \pm 0.4$ & $1.0 \pm 0.4$ \\
\hline \multirow[t]{2}{*}{ Proteus } & $1 \mathrm{a}$ & $0.1 \pm 0.1$ & $0.9 \pm 0.1$ & $1.1 \pm 0.2$ & $0.8 \pm 0.2$ & $0.4 \pm 0.2$ & $0.3 \pm 0.1$ & $0.5 \pm 0.2$ & 0 & 0 & 0 & 0 & 0 \\
\hline & $2 a$ & $0.1 \pm 0.1$ & $1.0 \pm 0.0$ & $0.9 \pm 0.1$ & $0.6 \pm 0.1$ & $0.4 \pm 0.1$ & 0 & $0.1 \pm 0.1$ & 0 & 0 & $0.1 \pm 0.1$ & 0 & 0 \\
\hline Clostridium & 1 & 0 & $0.2 \pm 0.1$ & $0.4 \pm 0.3$ & $0.4 \pm 0.3$ & $0.5 \pm 0.3$ & $0.3 \pm 0.3$ & 0 & 0 & 0 & 0 & 0 & 0 \\
\hline perfringens & 2 & 0 & 0 & $0.2 \pm 0.2$ & $0.1 \pm 0.1$ & $0.1 \pm 0.1$ & 0 & 0 & 0 & 0 & 0 & 0 & 0 \\
\hline \multirow[t]{2}{*}{ Klebsiella } & $1 \mathrm{a}$ & 0 & $0.7 \pm 0.3$ & $0.5 \pm 0.2$ & 0 & 0 & 0 & 0 & 0 & 0 & 0 & 0 & 0 \\
\hline & $2 a$ & 0 & $0.3 \pm 0.2$ & $1.1 \pm 0.3$ & $0.4 \pm 0.3$ & 0 & 0 & $0.4 \pm 0.3$ & 0 & 0 & 0 & 0 & 0 \\
\hline \multirow[t]{2}{*}{ Pseudomonas } & 1 & 0 & 0 & 0 & 0 & 0 & $0.3 \pm 0.3$ & 0 & $0.2 \pm 0.2$ & 0 & $0.5 \pm 0.3$ & $0.2 \pm 0.2$ & 0 \\
\hline & 2 & $0.1 \pm 0.1$ & 0 & 0 & 0 & 0 & 0 & 0 & $0.3 \pm 0.3$ & $0.3 \pm 0.3$ & 0 & 0 & 0 \\
\hline \multirow[t]{2}{*}{ Pantoea } & $1 \mathrm{a}$ & $0.7 \pm 0.3$ & $0.2 \pm 0.2$ & 0 & 0 & 0 & 0 & 0 & 0 & 0 & 0 & 0 & 0 \\
\hline & $2 a$ & $0.9 \pm 0.3$ & 0 & 0 & 0 & 0 & 0 & 0 & $0.5 \pm 0.3$ & 0 & 0 & 0 & 0 \\
\hline \multirow[t]{2}{*}{ Acinetobacter } & 1 & $0.4 \pm 0.3$ & $0.2 \pm 0.2$ & 0 & 0 & $0.3 \pm 0.3$ & 0 & $0.2 \pm 0.2$ & $0.3 \pm 0.3$ & 0 & $0.3 \pm 0.3$ & 0 & $0.2 \pm 0.2$ \\
\hline & 2 & $0.5 \pm 0.3$ & 0 & 0 & 0 & $0.1 \pm 0.1$ & 0 & $0.4 \pm 0.3$ & $0.6 \pm 0.4$ & $0.3 \pm 0.3$ & $0.2 \pm 0.2$ & 0 & 0 \\
\hline \multirow[t]{2}{*}{ Citrobacter } & 1 & 0 & $0.5 \pm 0.3$ & $0.5 \pm 0.3$ & $0.2 \pm 0.2$ & $0.3 \pm 0.3$ & 0 & 0 & 0 & 0 & 0 & $0.2 \pm 0.2$ & 0 \\
\hline & 2 & 0 & $0.3 \pm 0.2$ & $0.1 \pm 0.1$ & 0 & $0.2 \pm 0.2$ & 0 & 0 & 0 & 0 & 0 & 0 & 0 \\
\hline
\end{tabular}

*significant differences between groups ( $\mathrm{p}<0.05)$; a: significant changes within group over time ( $\mathrm{p}<0.01$; Friedman-test) 


\section{Figure legends}

Figure 1: Percentage of mares in first postpartum oestrous ( $\beta$-carotene treated, $\mathrm{n}=15 ; \square$ control, $\mathrm{n}=15$ ) and foals showing signs of diarrhoea during 42 days after foaling and birth, respectively ( 0 foals born to $\beta$-carotene-treated mares, $n=13$; 0 foals born to control mares, $n=14$ )

Figure 2: Percentage of $(a, c)$ mares ( $n=15$ per group) and (b, d) foals ( $n=13$ group1, $\mathrm{n}=14$ group 2) with E. coli, Enterococcus spp., $\beta$-haemolytic Streptococcus spp. and coagulase-negative Staphylococcus spp. in faecal swabs throughout the experimental period. Significant changes over time in mares of both groups for $\beta$ haemolytic Streptococcus spp. $(\mathrm{p}<0.05)$ and group 2 mares for coagulase-negative Staphylococcus spp. $(\mathrm{p}<0.01)$; in foals for E. coli, Enterococcus spp., $\beta$-haemolytic Streptococcus spp. and coagulase-negative Staphylococcus spp. $(p<0.001) ;{ }^{*} p<0.05$ between groups.

Figure 3: (a) Serum IGF-1 and (b) Y-globulin concentrations in foals born to Bcarotene-treated $(\bullet ; n=13)$ and control mares $(\bigcirc ; n=14)$. Significant changes over time for both IGF-1 $(p<0.001)$ and $y$-globulins $(p<0.001)$. 


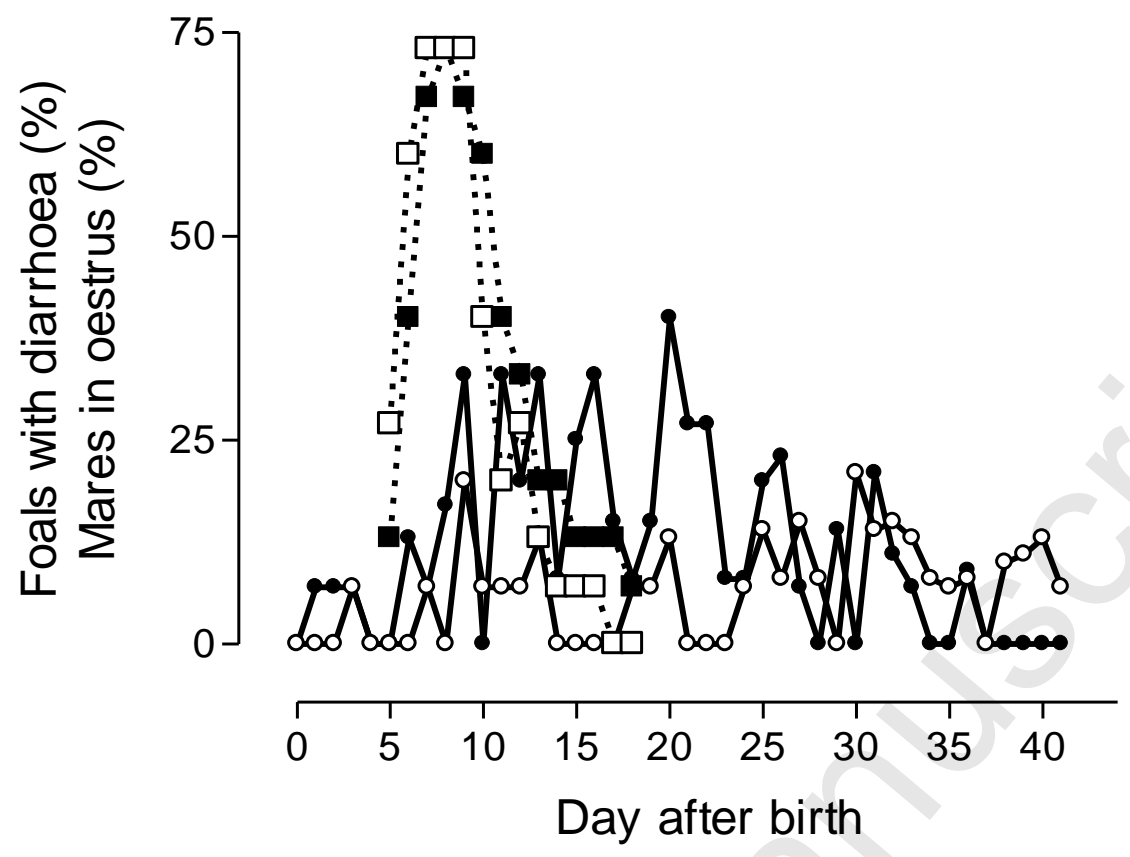

Kuhl et al., Figure 1 


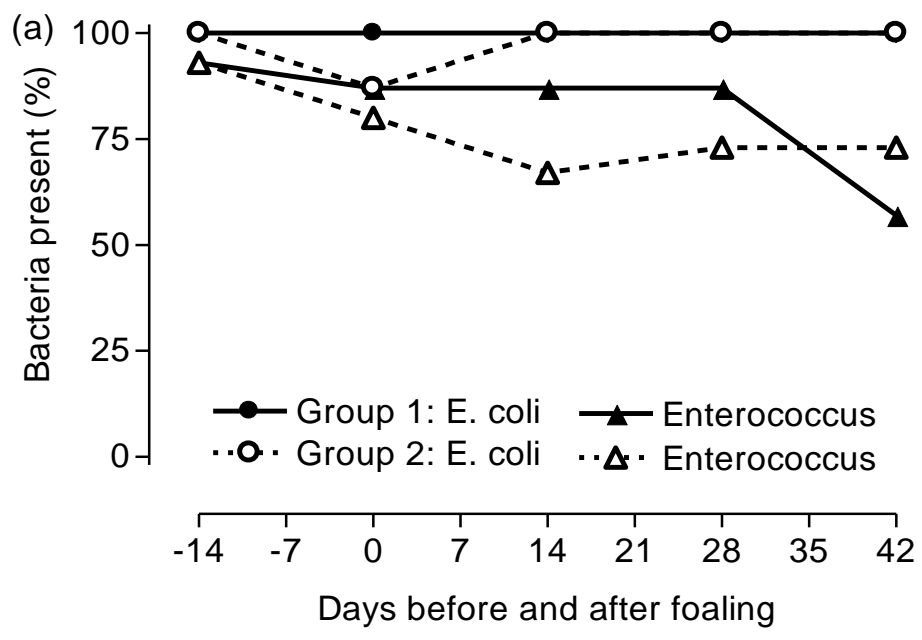

Kuhl et al., Figure $2 a$ 


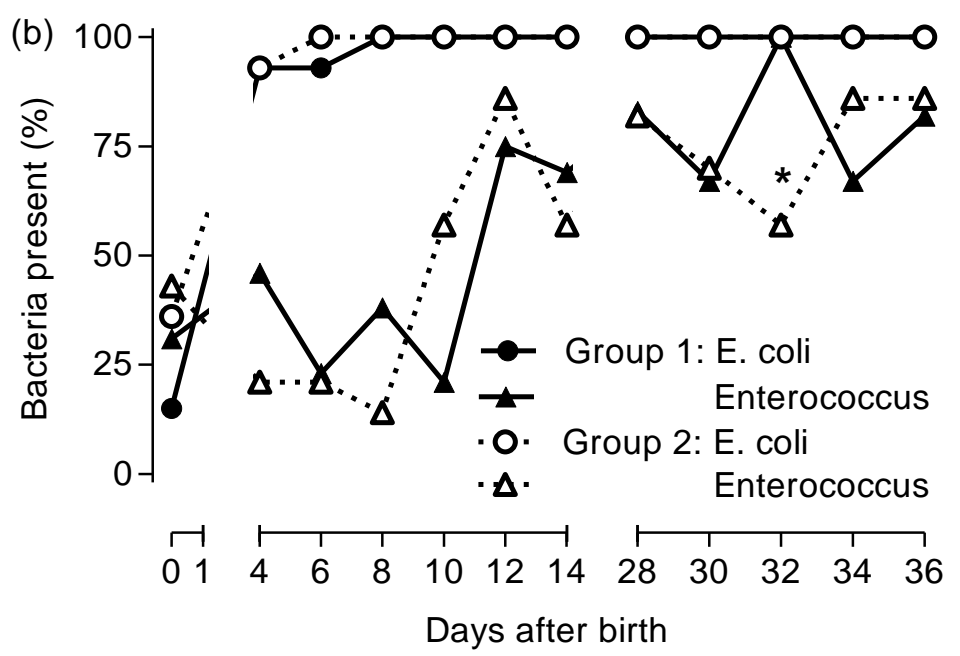

Kuhl et al., Figure $2 b$ 


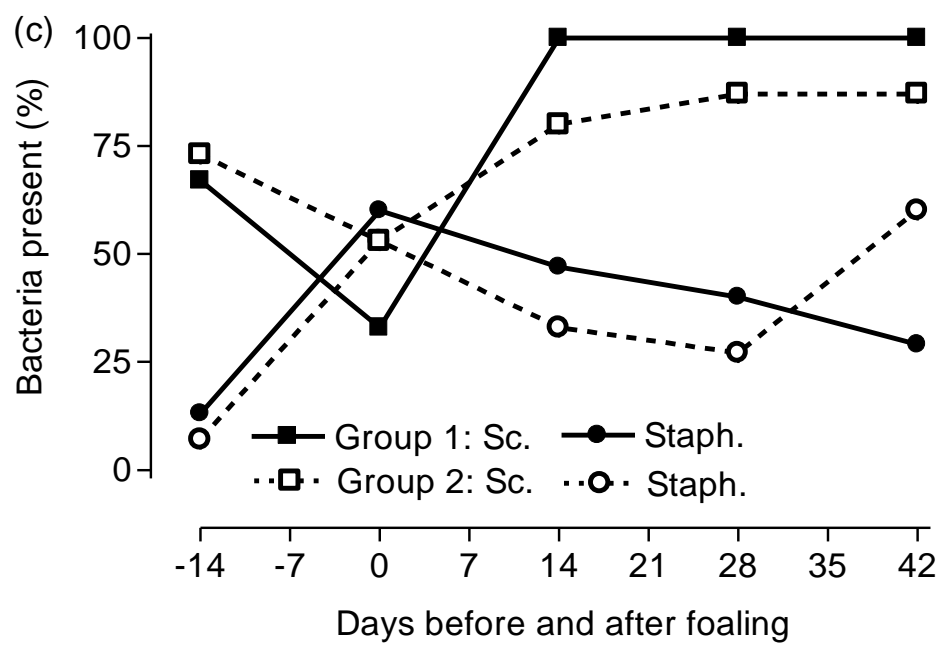

Kuhl et al., Figure $2 c$ 


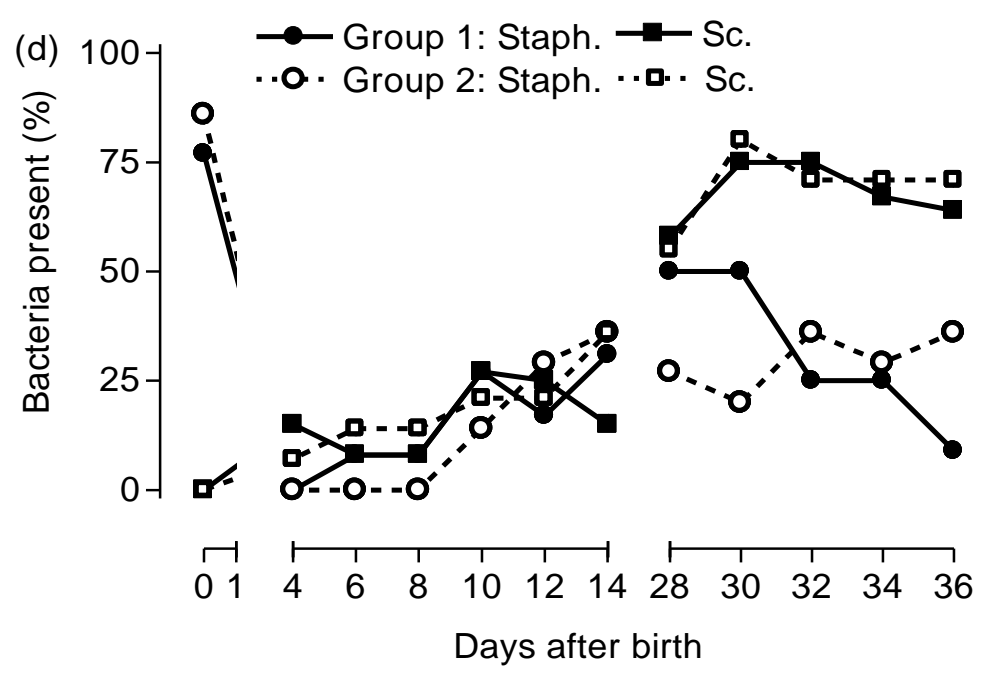

Kuhl et al., Figure $2 d$ 


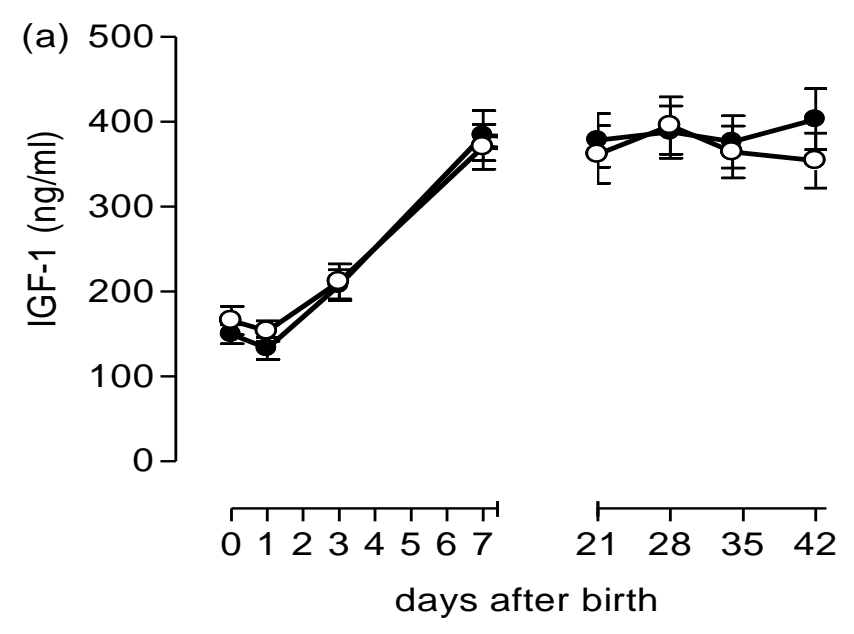

Kuhl et al., Figure $3 a$ 


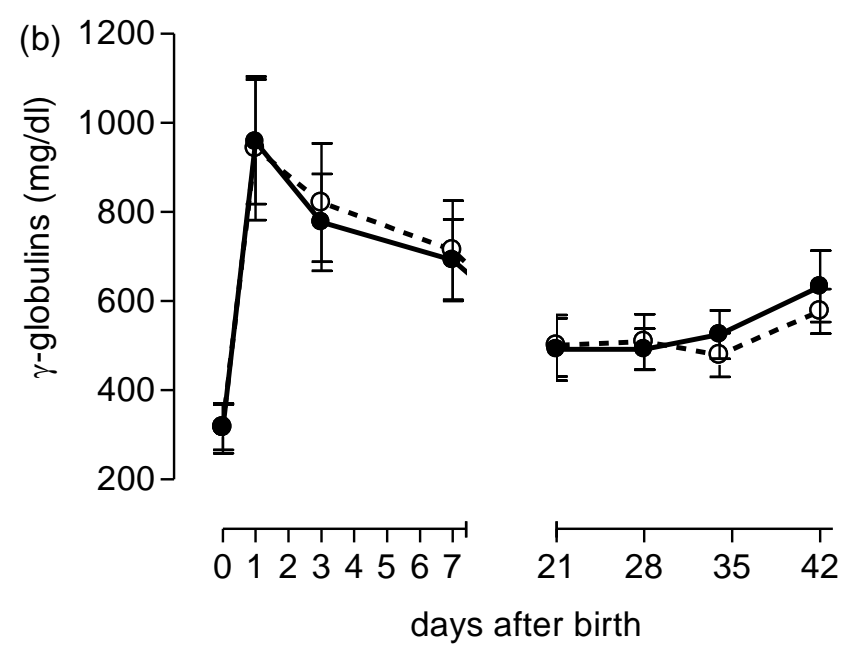

Kuhl et al., Figure $3 b$ 